\title{
THE CRETACEOUS VEGETATIONAL HISTORY OF THE TROPICS
}

CRANE*, Peter R., Department of Geology, Field Museum of Natural History, Roosevelt Road at Lake Shore Drive, Chicago, IL 60605, USA: and S. LIDGARD, Department of Geology, Field Museum of Natural History, Roosevelt Road at Lake Shore Drive, Chicago, IL 60605, USA:

The mid-Cretaceous (Aptian-Turonian) was a critical interval in the modernization of terrestrial ecosystems. In particular, the rapid transition from vegetation dominated by pteridophytes (ferns, lycopods and sphenopsids), cycadophytes (true cycads, Bennettitales, "pteridosperms" with pinnate foliage) and conifers, to one dominated by angiosperms marks a pivotal change in the evolution of terrestrial floras. Current knowledge of the paleoecological circumstances of this transition is still rudimentary and based almost entirely on macrofloras and palynofloras from mid-to high latitudes of the Northem Hemisphere. Information from low paleolatitude areas is especially sparse and based almost entirely on palynofloras. Ongoing syntheses of published palynological data document the similarity of mid-Cretaceous palynofloras in a broad equatorial zone ranging from Ecuador in the west to Papua-New Guinea in the east (Africa-South America Floristic Province of Herngreen). Palynofloras from this area are characterized by a high diversity and abundance of elaterate and ephedroid pollen grains (both probably gnetalean), low diversity of saccate conifer pollen grains and a paucity of pteridophyte spores relative to contemporaneous mid- and high latitude regions. Frequently, these palynofloras also show high levels of Afropollis and Classopollis-pollen (produced by probable winteroid angiosperms and extinct cheirolepidiaceous conifers respectively). Macrofossil floras corresponding to this low paleolatitude floristic assemblage are sparse but the assemblage of macrofossils now available from the from the Santana Formation (probable Albian) of north-eastem Brazil shows conifer leafy shoots (Araucariaceae or Cheirolepidiaceae) interspersed with macrofossils of ferns, various "pteridosperms"' occasional angiosperms, and possible Gnetales. Many of the plant fossils show structural features consistent with growth in arid environments (e.g., small leaf size, thick leaf textures, well-developed indumentum). The fossil record of woods from low latitude areas is difficult to evaluate because of uncertainties in dating many of the specimens that have been described. Previous analyses have suggested that woods from Cretaceous lowlatitudes show only faint growth rings, however, in recently collected specimens from the Albian of Niger growth rings are marked. Taken together, the weight of paleobotanical data are consistent with the distribution of climatically sensitive sediments (e.g., presence of evaporites and aeolian sands, absence of well-developed coals) which has been interpreted to reflect at least seasonal aridity. Although existing paleobotanical data are sparse they provide no evidence for rainforests in low latitude areas during the mid-Cretaceous.

Beginning at around the late Cenomanian palynofloras from low paleolatitudes undergo a substantial compositional change (the transition to the Palmae Floristic Province of Herngreen \& Chlonova). Classpollis pollen becomes much less abundant, the diversity and abundance of putative gnetalean pollen declines, while the abundance and diversity of angiosperm pollen (particularly forms probably referable to the Palmae) increases. Fossil woods associated with Campanian and Maastrichtian palynofloras from low latitudes show only weak evidence of growth rings. These data may imply a more equable distribution of rainfall than during the mid-Cretaceous and perhaps the initial, local, development of tropical rainforest vegetation. A latest Cretaceous-Early Tertiary initiation of tropical rainforest environments has important implications for patterns of diversification, not only in angiosperms but also in several of the most diverse lineages of nonangiosperm land plants, particularly the leafy liverworts (Jungermanniales), homosporous lycopods of the genus Huperzia , heterosporous lycopods of the genus Selaginella, and the "higher" filicalean ferns. In all of these groups the majority of extant species are restricted to tropical, frequently rainforest environments. While the origin of these groups may substantially predate the Cretaceous, the bulk of their extant diversity may have arisen over the last 70-50 million years. 